\title{
Chemical Stability, Compatibility and Shelf Life of Explosives
}

\author{
Beat Vogelsanger
}

\begin{abstract}
As with all highly energetic substances, explosives are not perfectly stable - their safety and functional features change during ageing. The extent of chemical instability strongly depends on the chemical structure of the explosive - aromatic and aliphatic nitro compounds, secondary nitramines, and organic azides are relatively stable, whereas aliphatic nitrate esters suffer from much lower stability. The rate of ageing of an explosive can be strongly accelerated by incompatibility reactions between the explosive and contact materials. Stability and compatibility of explosives can be investigated with numerous test methods. A classification of these test methods based on test design and type of investigated ageing phenomenon is suggested in this paper. Furthermore, the most important test methods are discussed regarding applicability, advantages, drawbacks, and pitfalls.
\end{abstract}

Keywords: Compatibility · Explosives · Propellants · Stability

\section{Introduction}

Explosives are energy-rich substances capable of releasing their energy after initiation at a high rate - this also in absence of oxygen. As all other energetic substances, explosives are thermodynamically unstable - they exist only for kinetic reasons. As a consequence, most explosives undergo slow chemical decomposition reactions already at room temperature and even more at elevated temperatures. This process involves numerous chemical decomposition mechanisms such as unimolecular decay with the formation of free radicals and consecutive radical reactions, oxidation and hydrolysis processes, and so on. Most of the processes are even self-accelerating [1].

\footnotetext{
${ }^{\star}$ Correspondence: Dr. B. Vogelsanger Nitrochemie Wimmis AG

These decomposition reactions cause two major problems, namely

(In)-stability: The safety and functional features of the explosive change during ageing.

Thermal explosion: As the decomposition reactions are strongly exothermic, conditions may appear in which the rate of heat release becomes larger than the rate of heat loss to the surroundings, leading to a temperature rise up to self ignition (thermal explosion).

As the explosives are rarely used on their own, but as components of a system (e.g. gas generator, ammunition, rocket), incompatibility reactions between the explosive and the other components of the system can further accelerate the rate of ageing, thereby enhancing the problems described above. As a consequence, stability and compatibility of an explosive have to be thoroughly investigated before the explosive can be safely manufactured, stored and used in technical applications.

Numerous stability and compatibility test procedures for explosives in military applications are described in several standards, the most important being STANAG (Standardisation Agreement of NATO/PfP), AOP-7 (Allied Ordnance Publication, contains all tests used in NATO/PfP countries during explosive qualification), MIL-STD (Military Standards, USA), DEF STAN (Defence Standards, GB), TL (Technische Lieferbedingungen, Germany), etc. The most important NA$\mathrm{TO} / \mathrm{PfP}$ standard on explosives safety is
STANAG 4170 which stipulates stability and compatibility testing during explosive qualification. STANAG 4170 contains no detailed test conditions, but refers to the specific STANAGs which should be used for the testing of the different explosives types. NATO/PfP nations are requested to utilize these STANAGs but can still use their national standards provided that these are listed in AOP-7.

A stability test for civil explosives is described in the UN 'orange book' [2] and, in a more sophisticated version, in EN 136312 (European Norm).

\section{Shelf Life of Explosives and Limiting Processes}

Service life (total use time period) is usually defined as the time interval during which the explosive can be stored, handled and used without any danger [3][4]. The service life consists of the safe storage and the functional life as follows (see also Fig. 1):

The safe (storage) life, also called chemical shelf life, covers the period of time during which the explosive can safely be stored without representing any hazard to its environment. The safe life is limited by the extent of chemical ageing reactions.

The functional life is the period of time during which the explosive can be used safely and during which the functional requirements remain fulfilled. The main factors which limit the functional life are (i) 


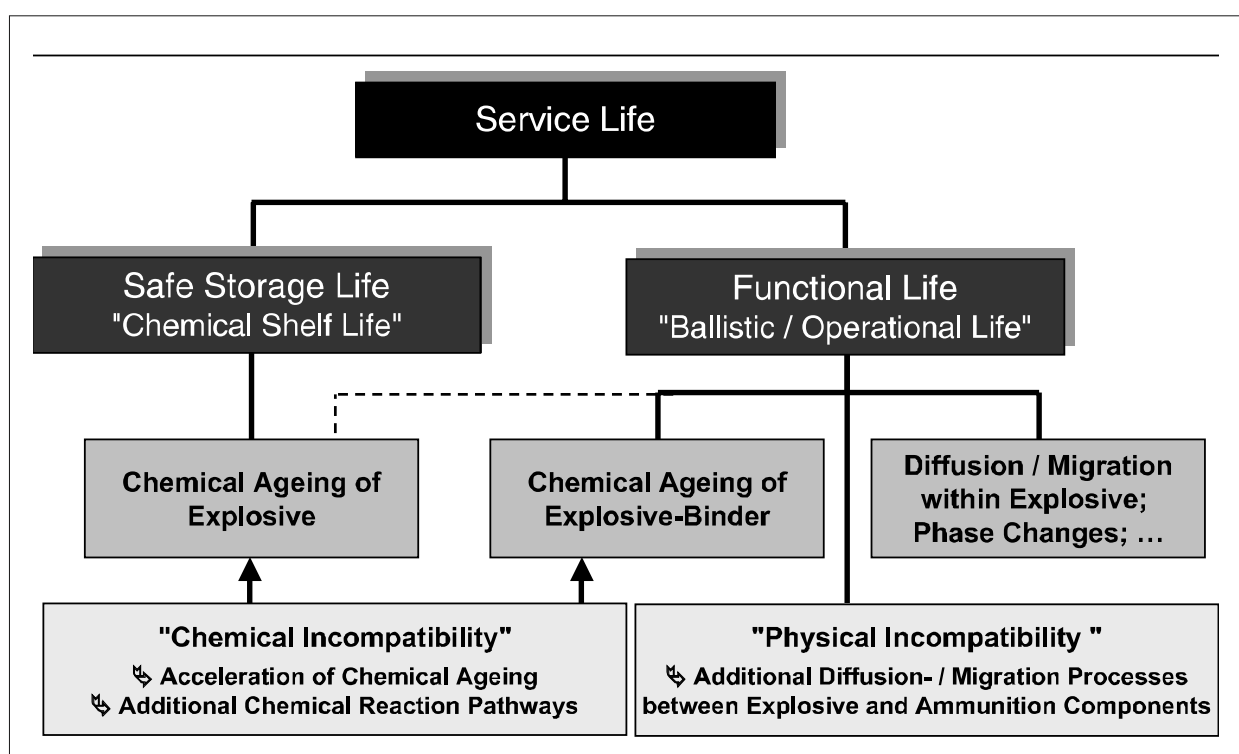

Fig. 1. Shelf life of explosives. For details see text.

chemical ageing of explosive (loss of energy content) or of explosive binder (changes in mechanical properties such as embrittlement due to additional cross-linking or degradation of binder) as well as (ii) physical processes within the explosive (such as diffusion or phase changes).

Incompatibility reactions can significantly alter the shelf life of explosives:

'Chemical incompatibility' can either accelerate the 'normal' ageing reactions or even activate new, additional ageing pathways. It affects both safe and functional life.

'Physical incompatibility' is caused by additional diffusion processes between explosive and other components of the system. It usually affects only functional life.

This work mainly focuses on chemical ageing and incompatibility reactions, including corresponding test methods. Nevertheless it should be noted that physical age- ing and incompatibility processes sometimes cause serious problems and are observed with ammunition more frequently than chemical problems. This is because they are difficult to detect during the development phase of an ammunition. Physical ageing and incompatibility effects can be identified by ageing of the entire system (e.g. ammunition), followed by functional testing.

\subsection{Chemical Ageing of Explosives}

Although the numerous types of explosives differ markedly in ageing behaviour and reactions, some common rules can be given:

Chemical ageing of pure (unmixed) organic explosive compounds often starts

\section{Chemical Stability}

with unimolecular (homolytic) decay of the weakest bond, followed and then accompanied by self-accelerating parallel reactions involving the formed decomposition products. In such cases, the activation energy ('bond energy of the weakest bond') of the homolytic decomposition is a good indicator of the thermal stability of the respective explosive. As a 'rule of thumb', explosives with an activation energy of decomposition higher than $170 \mathrm{~kJ} / \mathrm{mol}$ are stable for thousands of years at room temperature, whereas for values below $155 \mathrm{~kJ} / \mathrm{mol}$, chemical stability is limited and must be examined properly [1]. As can be seen from Table 1, the commonly used explosives from the classes of aromatic and aliphatic nitro compounds, secondary nitramines, and organic azides are very stable, whereas aliphatic nitrate esters suffer from much lower chemical stability. Other pure organic explosive compounds, such as organic peroxides, perchlorates, and nitrogen-rich heterocycles, also have to be placed often in the class of less-stable substances.

Inorganic explosive compounds (e.g. azides, acetylides and fulminates of lead, silver and mercury) cover the entire range from being chemically very stable (lead azide) to very unstable (mercury fulminate, which reacts with metals in a moist atmosphere).

Except for some rare examples (e.g. TNT), explosive compounds are not used alone but blended with other explosives and/or inert materials (e.g. binders). The chemical ageing characteristics of these explosive products are in most cases still dominated by the ageing behaviour of the main energetic components. High explosives retain the excellent chemically stability of their major components (aromatic nitro compounds and/or secondary nitramines). The same is true for current polymerbonded (rocket) propellants which contain

Table 1. Homolytically cleaved chemical bonds with respective activation energies for different classes of organic explosives

\begin{tabular}{|c|c|c|c|c|c|}
\hline Substance Class & Typical Representatives & Functional Group & $\begin{array}{l}\text { Homolytic De } \\
\text { Involved Bond }\end{array}$ & $\begin{array}{l}\text { composition } \\
\mathrm{E}_{\mathrm{A}}, \mathrm{kJ} / \mathrm{mol} \\
\text { (typical) }\end{array}$ & Chemical Stability \\
\hline $\begin{array}{l}\text { Aromatic Nitro } \\
\text { Compounds }\end{array}$ & $\begin{array}{c}\text { Trinitrotoluene TNT, Picric Acid, } \\
\text { Triaminotrinitrobenzene TATB, } \\
\text { Hexanitrostilbene HNS }\end{array}$ & $\mathrm{AR}-\mathrm{NO}_{2}$ & $\mathrm{C}-\mathrm{NO}_{2}$ & $\begin{array}{l}190-290 \\
{[1]}\end{array}$ & Excellent \\
\hline $\begin{array}{l}\text { Aliphatic Nitro } \\
\text { Compound }\end{array}$ & Nitromethane & $\mathrm{R}-\mathrm{NO}_{2}$ & $\mathrm{C}-\mathrm{NO}_{2}$ & $\begin{array}{l}230-260 \\
{[1]}\end{array}$ & Excellent \\
\hline $\begin{array}{l}\text { Aliphatic } \\
\text { Nitramines }\end{array}$ & $\begin{array}{l}\text { Hexahydrotrinitrotriazine RDX, } \\
\text { Octahydrotetranitrotetrazine HMX, } \\
\text { Nitroguanidine, Ethylendinitramine }\end{array}$ & $\mathrm{RR}{ }^{\prime} \mathrm{C}-\mathrm{N}-\mathrm{NO}_{2}$ & $\mathrm{~N}-\mathrm{NO}_{2}$ & $\begin{array}{c}170-200 \\
{[1]}\end{array}$ & Excellent \\
\hline $\begin{array}{l}\text { Aliphatic } \\
\text { Azides }\end{array}$ & $\begin{array}{l}\text { thylazide, Ethylenglcol-bis(acidoacetate) } \\
\text { A17, Glycidilazide polymer GAP }\end{array}$ & $\mathrm{RR} \cdot \mathrm{C}-\mathrm{N}-\mathrm{N}_{2}$ & $\mathrm{~N}-\mathrm{N}_{2}$ & $\begin{array}{c}165-170 \\
{[1]}\end{array}$ & Mostly good \\
\hline $\begin{array}{l}\text { Aliphatic } \\
\text { Nitrate Esters }\end{array}$ & $\begin{array}{l}\text { Cellulose nitrate NC, Glycerol trinitrate } \\
\text { NG, Pentaerythritoltetranitrate PETN }\end{array}$ & $\mathrm{R}-\mathrm{O}-\mathrm{NO}_{2}$ & $\mathrm{O}-\mathrm{NO}_{2}$ & $\begin{array}{c}155-190 \\
{[1]}\end{array}$ & $\begin{array}{l}\text { Between poor (NC, NG) } \\
\text { and good (PETN) }\end{array}$ \\
\hline
\end{tabular}


only stable explosive components (e.g. nitramines and/or ammonium nitrate and aluminium). The majority of gun propellants and many rocket propellants, however, are based on aliphatic nitric acid esters (nitrate esters) such as nitrocellulose (cellulose nitrates with a nitrogen content between 12.2 and 13.4 mass \%) and therefore suffer from much lower chemical stability.

A totally different ageing behaviour is found for pyrotechnics which are mixtures of oxidisers and fuels. Here, chemical degradation is mainly caused by oxidation and hydrolysis of the fuel (e.g. hydrolysis/corrosion of $\mathrm{Mg}$ by moisture or oxidation of $\mathrm{Al}, \mathrm{Mg}$ and $\mathrm{Ti}$ by oxygen).

\subsection{Chemical Ageing of Propellants}

As the problem of chemical ageing is most distinctive for propellants, a more detailed description of this case is given here:

As already mentioned, the chemical ageing of propellants starts with the homolytic breaking of the weak $\mathrm{O}-\mathrm{NO}_{2}$ bond of the aliphatic nitrate esters (e.g. nitrocellulose NC and nitroglycerine NG), thus forming nitrogen dioxide and the corresponding alkoxyl radical [1][5-7]:

$$
\mathrm{R}-\mathrm{O}-\mathrm{NO}_{2} \rightarrow \mathrm{R}-\mathrm{O} \cdot+\cdot \mathrm{NO}_{2}
$$

These reactive free radicals immediately undergo consecutive reactions with nearby nitrate ester molecules. In case of $\mathrm{NC}$, the 'backbone alkoxyl radical' $\mathrm{R}-\mathrm{O}$ ' also performs internal stabilization reaction by splitting off small stable molecules [5-7]:

$$
\begin{array}{ll}
\mathrm{R}-\mathrm{O}-\mathrm{NO}_{2}+\mathrm{R}-\mathrm{O} \cdot \boldsymbol{y} & \mathrm{N}_{2}, \mathrm{~N}_{2} \mathrm{O}, \cdot \mathrm{NO}, \cdot \mathrm{NO}_{2}, \\
& \mathrm{H}_{2} \mathrm{O}, \mathrm{H}_{2}, \mathrm{CO}_{2}, \mathrm{CO}, \\
\mathrm{R}-\mathrm{O}-\mathrm{NO}_{2}+\cdot \mathrm{NO}_{2} \geqslant \begin{array}{l}
\mathrm{C}_{2} \mathrm{H}_{2} \mathrm{O}_{4}, \text { other } \\
\text { fragments }
\end{array}
\end{array}
$$

Another main decomposition pathway is the neutral to acid hydrolysis of the nitrate esters. This reaction is catalysed by moisture and residual acids (which were not fully removed after nitrate ester synthesis), or by water and acids formed during decomposition [1][5][6]:

$$
\mathrm{R}-\mathrm{O}-\mathrm{NO}_{2}+2 \mathrm{H}_{2} \mathrm{O} \stackrel{\mathrm{H}^{+}}{\rightarrow} \mathrm{R}-\mathrm{OH}+\mathrm{HNO}_{3}
$$

A further decomposition reaction is the 'enhanced hydrolysis' caused by the interaction between nitrate groups and $\mathrm{N}_{2} \mathrm{O}_{4}$. It starts by converting the nitrate group to the nitrite group $\mathrm{R}-\mathrm{O}-\mathrm{NO}$, followed by hydrolysis of the $\mathrm{O}-\mathrm{NO}$ bond. This reaction was found with nitrogylcerine and has a significantly lower activation energy of $71 \mathrm{~kJ} / \mathrm{mol}$ compared to $100 \mathrm{~kJ} / \mathrm{mol}$ with the nitrate group. Therefore it can be a dominant decomposition reaction at lower temperatures [1].
Some of the reaction products of reactions (1) and (2) are further transformed in presence of moisture and oxygen [1][5-7]:

$$
\begin{aligned}
& 2 \cdot \mathrm{NO}+\mathrm{O}_{2} \rightarrow 2 \cdot \mathrm{NO}_{2} \leftrightarrow \mathrm{N}_{2} \mathrm{O}_{4} \\
& \cdot \mathrm{NO}+\cdot \mathrm{NO}_{2}+\mathrm{H}_{2} \mathrm{O} \rightarrow 2 \mathrm{HNO}_{2} \\
& 3 \cdot \mathrm{NO}_{2}+\mathrm{H}_{2} \mathrm{O} \rightarrow 2 \mathrm{HNO}_{3}+\cdot \mathrm{NO}
\end{aligned}
$$

The radicals and acids formed by reactions (1)-(6) strongly self-accelerate both radical (2) and hydrolytic (3) decomposition of the nitrate esters. This accelerating action is called autocatalysis.

Whereas the primary homolytic reaction (1) cannot be suppressed, the consecutive reactions (2)-(3) can be slowed down nearly to zero by binding or elimination of acids, nitric oxides, and water from the system. This fact is used for the stabilisation of explosives based on nitric esters [1][5-7]. The most widely used stabilisers are (a) aromatic amines and (b) urea derivatives both types are capable of binding nitric acid and nitric oxides. Examples for (a) are diphenylamine, 2-nitro-diphenylamine, $p$ nitro-N-ethylaniline, $p$-nitro-N-methylaniline and for (b) akardite-II (1-methyl-3,3diphenylurea) and ethyl centralite (1,3-diethyl-1,3-diphenylurea).

A simplified and more phenomenological picture of chemical ageing of propellants is given in Fig. 2.

\subsection{Stability Test Methods}

The numerous stability tests can be classified, among other criteria, according to (a) design of test method and (b) ageing phenomenon investigated.

Regarding test design/test philosophy (a), one can distinguish between:

- Shelf life prediction: This is the most elaborate test type, involving artificial ageing at different temperatures (typically between $40^{\circ} \mathrm{C}$ and $80{ }^{\circ} \mathrm{C}$ ) for relatively long periods of time (months to years) with different ageing time intervals, followed by analysis of the ageinginduced changes. A subsequent kinetic analysis and Arrhenius evaluation results the effective activation energy which allows the calculation of the shelf life at standard storage temperature. This test type yields the most reliable shelf life assessment, but is so timeconsuming and expensive that it is usually only performed during development/qualification of a new explosive. An example is given in Figs. 3 and 4.

- Single-temperature stability test: Here, artificial ageing is performed at only one moderate temperature (typically between $60{ }^{\circ} \mathrm{C}$ and $100{ }^{\circ} \mathrm{C}$ ) for only one time interval (usually several weeks). As the activation energy cannot be de-

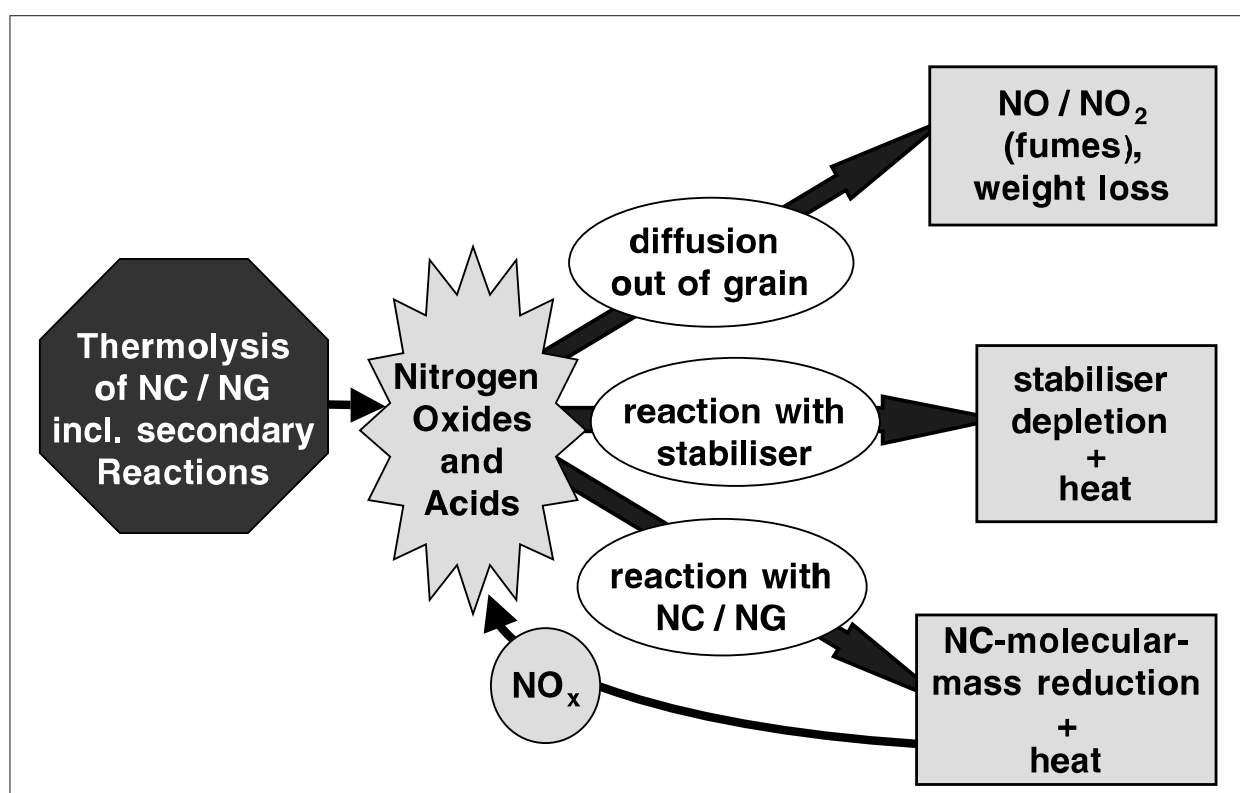

Fig. 2. Simplified scheme for the chemical ageing of propellants: Ageing starts with homolytic breaking of the nitrate ester bonds of nitrocellulose (NC) and nitroglycerine (NG). The very reactive nitrogen oxides and acids formed thereby and during consecutive reactions with moisture and oxygen should be trapped by the stabiliser, resulting in stabiliser consumption and evolution of heat. Nitrogen oxides and acids which are not captured quick enough can either further react with the nitrate esters of the propellant (thereby reducing the molecular mass of the NC and producing more heat and nitrogen oxides, which further accelerates propellant ageing), or diffuse out of the propellant (giving rise to the appearance of 'red fumes'; the leaving nitrogen oxides, together with the other escaping backbone decomposition products such as $\mathrm{H}_{2} \mathrm{O}, \mathrm{CO}_{2}, \mathrm{CO}$, and $\mathrm{N}_{2}$, also cause weight loss). 

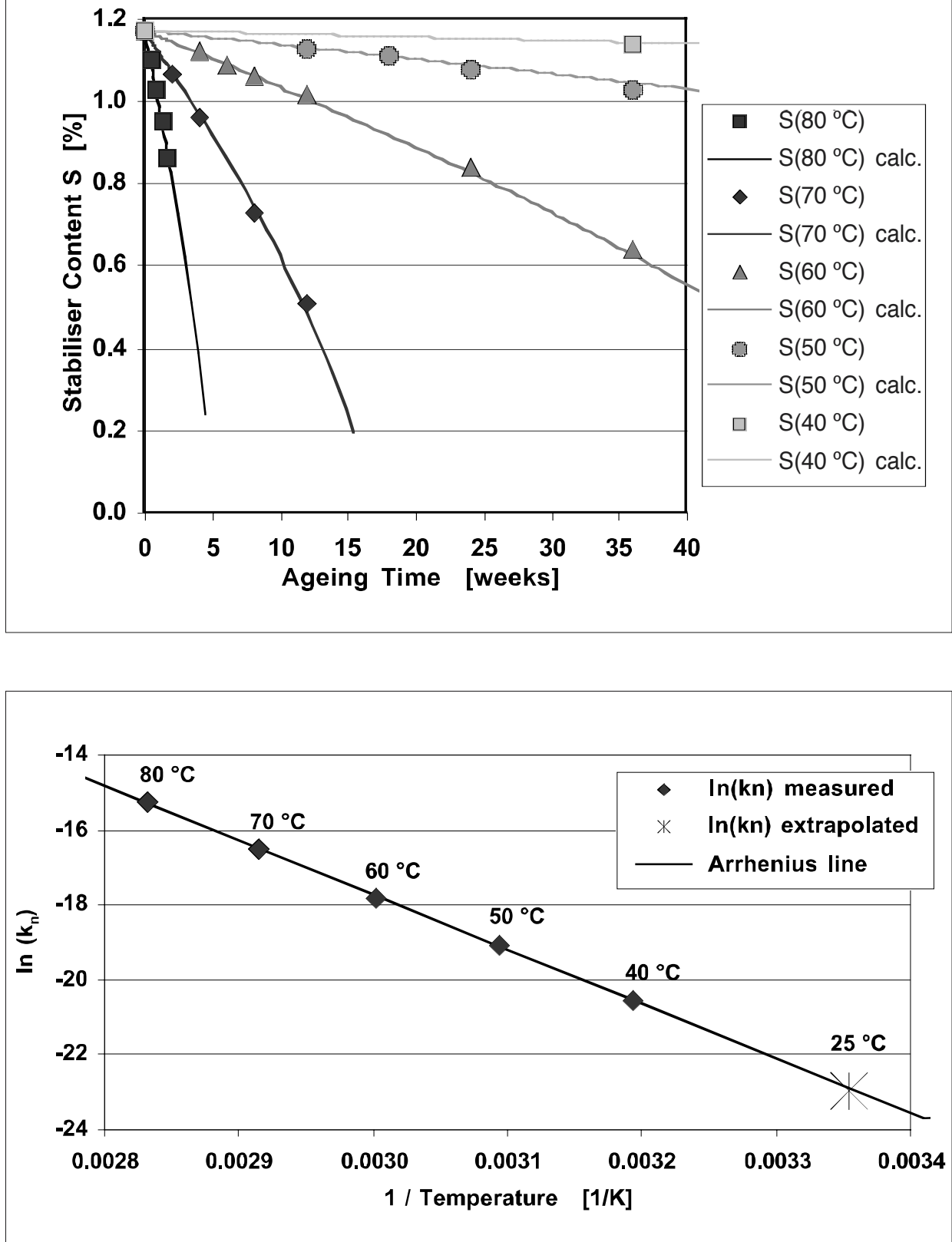

termined from only one single ageing temperature, extrapolation to lower temperatures has to be done using activation energy values obtained from experience including a safety margin. This results in a much less accurate prognosis. Typically, such tests determine whether the shelf life is shorter or longer than 5 or 10 years at $25^{\circ} \mathrm{C}$. As test time and cost are moderate, this test type is mostly used during explosive qualification and only rarely applied for quality control of produced lots and for storage surveillance.

- Conventional high temperature test: For this test type, ageing is performed at a relatively high temperature (typically between $90^{\circ} \mathrm{C}$ and $140{ }^{\circ} \mathrm{C}$ ) for a short period of time (from several hours to days). Here, the ageing conditions are so far from real ageing that no shelf life prognosis can be given - this test only allows a 'good'/"bad' ('stable'/'instable') decision. On the other hand, these conventional tests are much faster and cheaper than the test types described above. This makes them especially suited for quality control and for storagesurveillance testing.

- 'Snapshot': This last type of test consists of a single chemical analysis (or functional test) and gives information about the actual condition of the explosive. This is required for control of each produced batch or during surveillance. As this test does not involve artificial ageing, no prognosis of ageing behaviour is obtained (except in case of explosive surveillance, where the course of natural ageing can be moni-
Fig. 3. Shelf-life assessment based on stabiliser depletion. The stabiliser content was determined using HPLC after accelerated ageing of the propellant for up to 36 weeks at $80^{\circ} \mathrm{C}, 70^{\circ} \mathrm{C}, 60^{\circ} \mathrm{C}$, $50^{\circ} \mathrm{C}$, and $40^{\circ} \mathrm{C}$, respectively. Kinetic evaluation gives best fit for reaction order $\mathrm{n}=-0.45$ (slightly autocatalytic).
Fig. 4. Arrhenius diagram of stabiliser depletion rate constants. The obtained activation energy value of $122 \mathrm{~kJ} / \mathrm{mol}$ allows reliable extrapolation to standard temperature. Thus, a chemical shelf life of 145 years at $25^{\circ} \mathrm{C}$ is calculated (basis: $50 \%$ stabiliser depletion).

tored over a long time by consecutive 'snapshots').

The second type (b) of test classification is based on the ageing phenomenon investigated which are mostly stabiliser depletion, heat production, evolution of nitrogen oxides or other gases (amount of evolved gas; time until produced gases become visible or cause colour change of indicator paper), mass loss, and functional testing.

An overview of the common stability test methods, arrayed according to these two criteria, is given in Table 2.

Most of these methods were designed for propellant testing, but some of them are also applicable to other explosives. An overview of test applicability as described in STANAG 4170 and EN 13631-2 can be found in Table 3. 
Table 2. Common stability-test methods, arranged according to test structure and type of investigated ageing phenomenon. Parentheses mark tests which are not standardised, but can be implemented analogous to the respective standardised tests. For example, changes in functionality, binder degradation or diffusion phenomena can be investigated using multi-temperature ageing and data analysis such as described in STANAG 4527 for stabiliser depletion.

\begin{tabular}{|c|c|c|c|c|}
\hline Criterion & Shelf Life Prediction & $\begin{array}{l}\text { Single-Temperature } \\
\text { Stability Test }\end{array}$ & $\begin{array}{l}\text { High-Temperature } \\
\text { Stability Test }\end{array}$ & 'Snapshot' \\
\hline Stabiliser Depletion & STANAG 4527 & $\begin{array}{c}\text { STANAG } 4117,4541 \\
4542, \text { AOP } 7\end{array}$ & - & Stabiliser Content \\
\hline Heat Evolution & (HFC at different T) & STANAG 4582 & EN 13631-2 & - \\
\hline $\mathrm{NO}_{\mathrm{x}}$ Evolution & - & $\begin{array}{c}65.5^{\circ} \mathrm{C} \text { Surveillance } \\
\left(\mathrm{NO}_{\mathrm{x}} \text {-Chemiluminescence) }\right.\end{array}$ & $\begin{array}{c}\text { Bergmann-Junk, Abel, } \\
\text { Vieille, Methyl Violet, } \\
\text { Red Gas Test }\end{array}$ & - \\
\hline Gas Evolution & - & - & Vacuum Stability, Taliani & - \\
\hline Mass Loss & - & - & $\begin{array}{l}\text { Dutch Test, } \\
90^{\circ} \mathrm{C} \text { Weight Loss }\end{array}$ & - \\
\hline Functional Changes & (Analogous 4527) & (4 weeks $\left.71^{\circ} \mathrm{C}\right)$ & - & Functionality \\
\hline Binder Degradation & (Analogous 4527) & (4 weeks $\left.71^{\circ} \mathrm{C}\right)$ & - & e.g. NC Molecular Mass \\
\hline Diffusion & (Analogous 4527) & (4 weeks $71^{\circ} \mathrm{C}$ ) & - & - \\
\hline
\end{tabular}

Table 3. Stability test methods for explosives according to STANAG 4170 and EN 13631-2. The explosive classes are: $\mathrm{C}=$ composite propellants; HE = high explosives; $\mathrm{PE}=$ primary explosives; $\mathrm{Py}=$ pyrotechnics; $\mathrm{P}=$ nitrocellulose-based propellants.

\begin{tabular}{|c|c|c|c|c|c|}
\hline $\begin{array}{l}\text { Test Principle / } \\
\text { Observed Effect }\end{array}$ & Applicable for & Temperature & $\begin{array}{l}\text { Ageing } \\
\text { Period }\end{array}$ & $\begin{array}{l}\text { Requirements (usually for Assessment } \\
\qquad 10 \text { Years at } 25^{\circ} \mathrm{C} \text { ) }\end{array}$ & STANAG \\
\hline $\begin{array}{l}\text { Single-temperature ageing and } \\
\text { analysis of stabiliser depletion }\end{array}$ & $\begin{array}{l}\mathrm{P}(\text { single base with } \\
\mathrm{DPA} \text { and/or EC; double } \\
\text { base with EC) }\end{array}$ & $65.5^{\circ} \mathrm{C}$ & $\begin{array}{l}120 \mathrm{~d} \\
\text { (or } 60 \mathrm{~d} \text { with } \\
\text { stricter } \\
\text { requirements) }\end{array}$ & $\begin{array}{c}\mathrm{DPA}_{\text {eff }} \geq 0.3 \% \text {; abs. depletion } \leq 0.5 \% \\
\text { EC } \geq 0.3 \% \text {; rel. depletion } \leq 50 \%\end{array}$ & 4117 \\
\hline \multirow{2}{*}{$\begin{array}{c}\text { Stabilisers: } \\
\mathrm{DPA}=\text { diphenylamine; } \\
\mathrm{EC}=\text { ethyl centralite } \\
\text { 2- } \mathrm{NO}_{2}-\mathrm{DPA}=\text { 2-nitro-DPA }\end{array}$} & $\begin{array}{l}\mathrm{P} \text { (double base with } \\
\quad \leq 15 \% \text { NG; } \\
\text { stabilised with DPA) }\end{array}$ & $60{ }^{\circ} \mathrm{C}$ & $60 \mathrm{~d}$ & $\begin{array}{l}\qquad \mathrm{DPA}_{\text {eff }} \geq 0.5 \% \\
\text { relative depletion } \leq 50 \%\end{array}$ & 4541 \\
\hline & $\begin{array}{l}\mathrm{P} \text { (double base with } \\
\leq 15 \% \mathrm{NG} \text {; stabilised } \\
\left.\text { with } 2-\mathrm{NO}_{2}-\mathrm{DPA}\right)\end{array}$ & $60^{\circ} \mathrm{C}$ & $35 d$ & $\begin{array}{l}2-\mathrm{NO}_{2}-\mathrm{DPA} \geq 0.2 \% \\
\text { total depletion } \leq 0.5 \%\end{array}$ & 4542 \\
\hline $\begin{array}{l}\text { Multi-temperature ageing and } \\
\text { analysis of stabiliser depletion }\end{array}$ & $P$ & $40^{\circ} \mathrm{C}-80^{\circ} \mathrm{C}$ & $\begin{array}{l}\text { Several } \\
\text { different } \\
\text { periods }\end{array}$ & $\begin{array}{l}\text { Kinetic analysis; Arrhenius evaluation; } \\
\text { no requirements given }\end{array}$ & 4527 \\
\hline $\begin{array}{l}\text { Recording of heat production at } \\
\text { constant temperature using heat } \\
\text { flow calorimetry HFC }\end{array}$ & $P$ & \multicolumn{2}{|c|}{$\begin{array}{l}10.6 \mathrm{~d} \text { at } 80^{\circ} \mathrm{C} \\
\text { or equivalent } \mathrm{T} / \mathrm{t} \text {-sequence }\end{array}$} & $\begin{array}{c}\text { Maximum heat flow } \leq 114 \mu \mathrm{W} / \mathrm{g} \text { at } 80^{\circ} \mathrm{C} \text { or } \\
\text { equivalent value for respective } \\
\text { temperature }\end{array}$ & 4582 \\
\hline $\begin{array}{l}\text { Vacuum stability test; single- } \\
\text { temperature ageing and } \\
\text { recording of amount of gas } \\
\text { evolved }\end{array}$ & P, C, Py, HE & $\begin{array}{l}\left(90^{\circ} \mathrm{C}\right) \\
100^{\circ} \mathrm{C} \\
\left(120^{\circ} \mathrm{C}\right)\end{array}$ & $40 \mathrm{~h}$ & $\begin{array}{l}\text { No criteria for gas production given in } \\
\text { STANAG } 4556, \text { nation-specific criteria } \\
\text { in AOP-7, e.g. USA: } \leq 2 \mathrm{ml} / \mathrm{g} \text { in } 48 \mathrm{~h} \text { at } \\
100^{\circ} \mathrm{C} \text { for all explosives; GE: } \leq 1.2 \mathrm{ml} / \mathrm{g} \text {, } \\
\text { double/triple base propellants } 40 \mathrm{~h} \text { at } 90^{\circ} \mathrm{C} \text {, } \\
\text { single base propellants and other } \\
\text { explosives } 40 \mathrm{~h} \text { at } 100^{\circ} \mathrm{C}\end{array}$ & 4556 \\
\hline $\begin{array}{l}\text { Thermal characterisation using } \\
\text { DTA, DSC or TG }\end{array}$ & HE, PE, Py, P, C & \multicolumn{2}{|c|}{$\begin{array}{l}\text { Suggests heating rates for } \\
\text { individual explosives }\end{array}$} & No criteria given & 4515 \\
\hline $\begin{array}{l}\text { Single-temperature ageing and } \\
\text { measuring of temperature rise }\end{array}$ & HE, P, C & $75^{\circ} \mathrm{C}$ & $48 \mathrm{~h}$ & $\begin{array}{l}\text { Stable if temperature rise }<3{ }^{\circ} \mathrm{C} \text { and if no } \\
\text { incident (self ignition, explosion, ...) occurs }\end{array}$ & EN 13631-2 \\
\hline
\end{tabular}



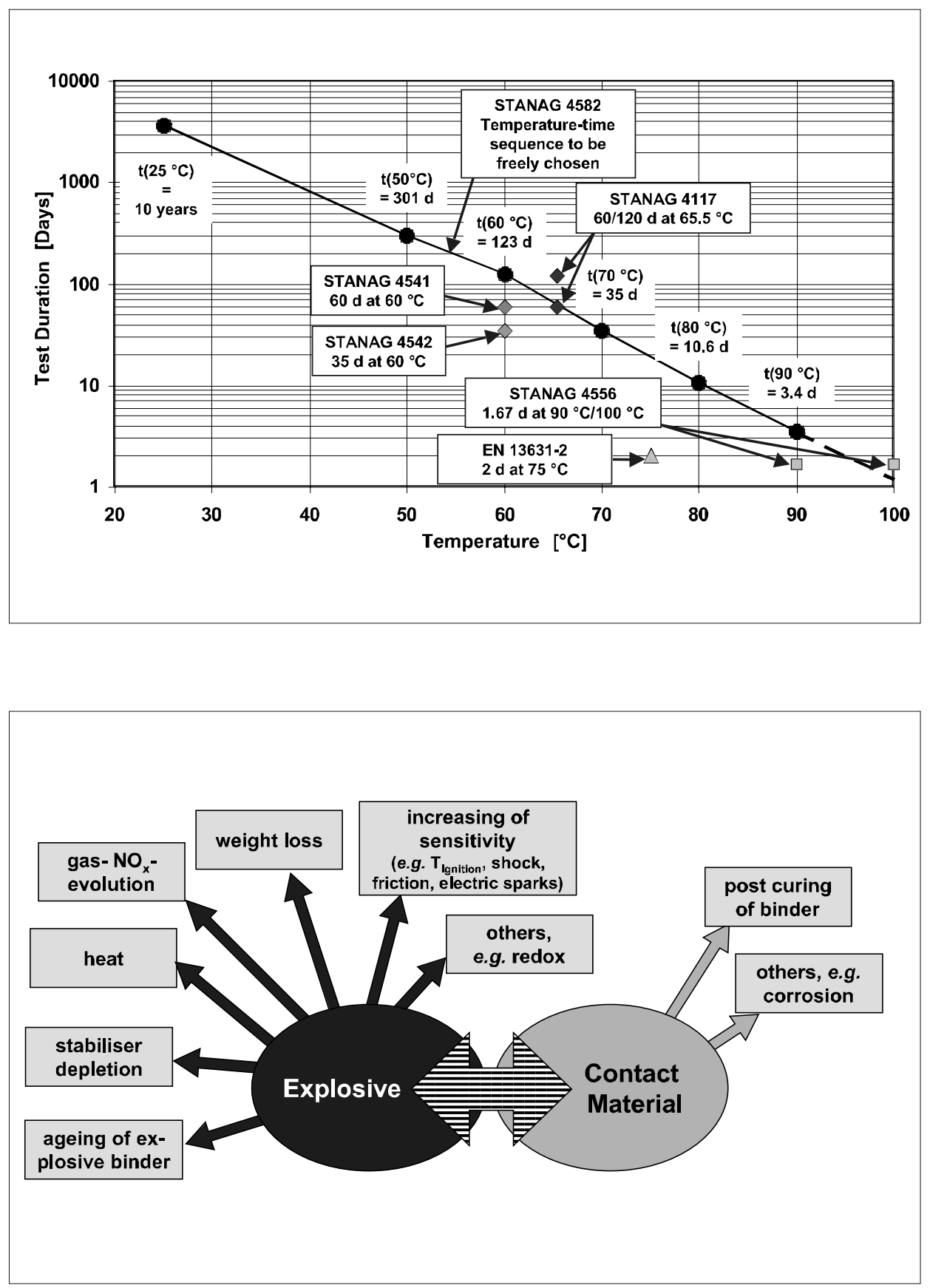

Fig. 5 shows test temperatures and durations of the individual STANAG and EN single-temperature stability tests for propellants. Only the heat flow calorimetry test (STANAG 4582 for NC-based propellants) allows a free choice of test temperature and corresponding test duration. It is based on an Arrhenius extrapolation to 10 years shelf life at $25^{\circ} \mathrm{C}$ by assuming an activation energy of $120 \mathrm{~kJ} / \mathrm{mol}$ above $60{ }^{\circ} \mathrm{C}$ and of $80 \mathrm{~kJ} / \mathrm{mol}$ below this temperature. The remaining tests are based on other assumptions, mainly for historic reasons. It is planned to merge all tests based on stabiliser depletion together into one single standard (STANAG 4620/AOP-48 Ed. 2), thereby also adopting the test conditions of STANAG 4582.

\section{Chemical Compatibility of Explosives}

\subsection{Chemical Incompatibility \\ Reactions}

In contrast to the chemical ageing reactions, incompatibility is much less understood. Therefore, only a phenomenological description is given here - the most important effects/phenomena as produced by chemical incompatibility reactions between explosive and contact material are depicted in Fig. 6.

From the analysis of numerous compatibility tests, it was concluded that contact materials which are found to be incompatible with one class of organic explosives very often are also incompatible with the other
Fig. 5. Test temperatures and durations of single-temperature stability tests for propellants. It can be seen that the test conditions of STANAG 4117 are slightly stricter, the ones of STANAG 4541 and 4542 less strict than the ones of STANAG 4582. The conditions of all STANAG tests, however, are more strict than the test conditions of EN 13631-2, meaning that stability requirements for military propellants are much stronger than those for civil applications.
Fig. 6. Phenomenological description of incompatibility: Chemical reactions between explosive and contact material can, on the explosive, increase the rate of binder degradation, stabiliser depletion, heat and gas production and weight loss. Furthermore, the sensitivity of the explosive can be increased. On the other hand, also chemical reactions of the contact material can be initiated, such as post curing and decomposition of binders and corrosion processes in container materials.

classes [8]. The experience-based rules regarding contact materials are as follows:

Inorganic contact materials: Neutral and slightly acidic inorganic compounds are usually compatible, whereas strong acids and strong oxidizers are often incompatible and strong alkalis are generally incompatible with explosives [8][9]. Furthermore, commonly used metals and alloys are compatible with explosives [8][9].

Organic contact materials: Most polymers are compatible with explosives. Glues and varnishes sometimes give rise to incompatibility, in particular when their curing is caused by chemical reactions rather than by solvent evaporation [8-10]. Here, amine- and polyamide hardeners in epoxy-based glues and isocyanates in 
Table 4. Compatibility tests as described in STANAG 4147. For definition of acceptance criteria M and D see text. The first figure describes the respective criterion for assessment as 'compatible', the second figure as 'not compatible'. The explosive classes are labelled as in Table 3 . It has to be noted that this STANAG is under revision - it is planned to introduce additional criteria to tests 1,2 and 5 A, as well as to introduce a sophisticated thermokinetic analysis for tests 3 and 4 .

\begin{tabular}{|c|c|c|c|c|c|c|c|}
\hline \multirow[t]{2}{*}{ Test } & \multirow{2}{*}{$\begin{array}{l}\text { Investigated } \\
\text { Effect }\end{array}$} & \multirow{2}{*}{$\begin{array}{l}\text { Mix- } \\
\text { ture } \\
\text { Ratio }\end{array}$} & \multirow[t]{2}{*}{ Test Sequence } & \multicolumn{2}{|c|}{ Criteria } & \multirow{2}{*}{$\begin{array}{l}\text { Applicable } \\
\text { For }\end{array}$} & \multirow{2}{*}{$\begin{array}{c}\text { STANAG } \\
4147\end{array}$} \\
\hline & & & & $\begin{array}{l}\text { Absolute } \\
\text { Incomp. (R) }\end{array}$ & $\begin{array}{c}\text { Relative } \\
\text { Incomp. (D) }\end{array}$ & & \\
\hline Vacuum Stability (VST) & $\begin{array}{l}\text { Volume of } \\
\text { gas evolved }\end{array}$ & $1: 1$ & $\begin{array}{l}40 \mathrm{~h} 100^{\circ} \mathrm{C} \\
240 \mathrm{~h} 80^{\circ} \mathrm{C}\end{array}$ & $\begin{array}{l}V_{\mathrm{R}}[\mathrm{ml} / 5 \mathrm{~g}] \\
\leq 5 />5\end{array}$ & - & $\mathrm{HE}, \mathrm{P}, \mathrm{C}$ & Test 1 \\
\hline $\begin{array}{l}\text { Heat Flow Calorimetry } \\
\text { (HFC) }\end{array}$ & $\begin{array}{l}\text { Amount of heat } \\
\text { released }\end{array}$ & $1: 1$ & $\begin{array}{c}7 \mathrm{~d} 85^{\circ} \mathrm{C} \\
-\end{array}$ & - & $\begin{aligned} & D[-] \\
\leq & 2 />3\end{aligned}$ & $\mathrm{HE}, \mathrm{P}, \mathrm{C}$ & Test 2 \\
\hline Thermogravimetry (TGA) & Weight loss & $1: 1$ & $\begin{array}{l}\text { Heating rate } \\
2{ }^{\circ} \mathrm{C} / \mathrm{min} \\
1000 \mathrm{~min} \text { at } \\
\text { selected T }\end{array}$ & $\begin{array}{l}\text { Difference in } \\
\text { weight loss } \\
\begin{array}{l}M-M_{\text {calc }}[\%] \\
\leq 4 />20\end{array}\end{array}$ & - & $\begin{array}{l}\mathrm{HE},(\mathrm{P}), \mathrm{C} \\
\text { Py, PE }\end{array}$ & $\begin{array}{c}\text { Test 3A } \\
\text { (dynamic) } \\
\text { Test 3B } \\
\text { (isothermal) }\end{array}$ \\
\hline $\begin{array}{l}\text { Differential Scanning } \\
\text { Calorimetry (DSC) }\end{array}$ & $\begin{array}{l}\text { Reduction of } \\
\text { decompos. T }\end{array}$ & $1: 1$ & $\begin{array}{l}\text { Heating rate } \\
2^{\circ} \mathrm{C} / \mathrm{min}\end{array}$ & $\begin{array}{l}\Delta \mathrm{T}_{\text {decomp }}\left[{ }^{\circ} \mathrm{C}\right] \\
\geq-4 /<-20\end{array}$ & & $\begin{array}{l}\text { HE, }(P), C \\
\text { Py, PE }\end{array}$ & Test 4 \\
\hline $\begin{array}{l}\text { Ageing }+ \text { Chemical } \\
\text { Analysis (HPLC) }\end{array}$ & Stabiliser depletion & $10: 1$ & $\begin{array}{l}14 \mathrm{~d} 80^{\circ} \mathrm{C} \\
\text { or suitable }\end{array}$ & - & $\begin{array}{c}D[-] \\
\leq 1.5 />1.5\end{array}$ & $\mathrm{P}$ & Test 5A \\
\hline
\end{tabular}

polyurethane products are often responsible for incompatibility with explosives. Incompatibilities are sometimes also found with acrylate and methacrylate glues and silicone paints [11].

Regarding explosives, it was found that less stable energetic materials such as primary explosives and aliphatic nitrate esters are generally more susceptible towards incompatibilities than the more stable high explosives [8][9]. Thus there are some additional incompatibilities which are specific or more distinctive for the individual explosive classes:

Propellants based on aliphatic nitrate esters, in particular if they contain nitroglycerine, are often incompatible also with nitrates and halogenides of alkaline metals [11], bitumen varnishes and black powder.

Some azides are strongly incompatible with non-ferrous heavy metals such as copper - thus, instable and dangerous copper azides are formed.

Pyrotechnics are usually compatible with inert and nitrocellulose-based binders but often incompatible with energetic polymer binders [12].

\subsection{Compatibility Test Methods}

The most important standard, which describes the testing and assessment of chemical compatibility, is STANAG 4147. According to this standard, the purpose of a compatibility test is "to provide evidence that a material may be used in an item of ammunition without detriment to the safety or reliability of an explosive with which it is in contact or proximity".
The individual compatibility tests are based on the different effects/phenomena as already shown in Fig. 6. Table 4 gives an overview of the test methods described in STANAG 4147, including some test conditions, acceptance criteria and applicability.

In particular the vacuum stability test (VST), heat flow calorimetry test (HFC) and stabiliser depletion test artificially age relatively large amounts (several grams) of explosive, contact material and mixture under sealed (ammunition-like) conditions all three tests are therefore perfectly suitable for nitrocellulose-based propellants; the VST and HFC tests are also suitable for high explosives and composite propellants. Due to the large sample masses, however, testing of primary explosives and pyrotechnics is too dangerous with these methods.

On the other hand, thermogravimetric analysis (TGA) and differential scanning calorimetry (DSC) use very small samples (several milligrams). They are therefore suitable for the testing of primary explosives and pyrotechnics, whereas their applicability for propellants must be questioned.

Other tests, which are not included in STANAG 4147, might also yield important information. In particular the analysis of binder degradation (nitrocellulose molecular mass reduction in case of propellants) often clarifies the ageing/incompatibility processes taking place in the explosive under investigation.

Furthermore, the changes in the sensitivity of the explosive (sensitivity to initiation by shock, friction, electrostatic discharge or heat) due to incompatibility reactions allow judgement of the additional safety risk, which can appear in the mixture.

For the evaluation of test results, different approaches are in use, such as 'absolute' incompatibility $\left(\mathrm{R}=\mathrm{M}-\mathrm{M}_{\text {calc }}\right)$ and 'relative' incompatibility $\left(\mathrm{D}=\mathrm{M} / \mathrm{M}_{\text {calc }}\right)$. $\mathrm{M}$ is the specific property (e.g. heat release, evolved gas volume, stabilizer depletion) as measured for the mixture, and $\mathbf{M}_{\text {calc }}$ the same property calculated for the mixture by linear combining the measured values of isolated explosive and contact material. $\mathbf{M}$ itself can be used as third criterion ('stability of the mixture') considering that, if two materials are regarded as compatible, their mixture has to be chemically stable as well and therefore must fulfil the stability test requirements of the respective explosive.

\section{Discussion/Conclusions}

The detailed knowledge of the chemical stability and the awareness of incompatibility reactions of an explosive with potential contact materials are the two major prerequisites in order to guarantee the necessary level of safety of the respective explosive over the entire life cycle. The basis for this knowledge is the understanding of decomposition, ageing and incompatibility reactions, as well as the availability of reliable and widely accepted stability and compatibility test methods.

Whereas the chemical ageing of explosives is well investigated and the reaction mechanisms taking place are at least generally understood, chemical incompatibility turns out to be much more complex. This 
results in a general lack of knowledge about details of the involved mechanisms. Thus, a phenomenological approach has to be adopted.

Regarding testing it has to be noted that as so many different stability and compatibility test methods exist, they are difficult to survey. The test classification scheme given in this paper should help to clarify this issue.

Even if standardised test procedures are available, stability and compatibility testing is not straightforward, leading to numerous pitfalls. The experimental conditions chosen (e.g. sample preparation, moisture content, loading density, material of test vial, tightness of seal, test temperature, contact area, ...) will influence the outcome of the investigation [13] - these conditions are usually not fully standardised and differ from test to test. It therefore has to be decided as the case arises which test conditions will best simulate natural ageing.

Furthermore, different test methods often yield different, sometimes even totally contradictory results - this since each particular ageing and incompatibility reaction stipulates different effects. For example, if a very efficient stabiliser is used in a propellant, ageing induced stabiliser depletion will dominate over nitrocellulose molecular mass reduction and nitrogen oxide evolution. If this stabilizer is replaced by a much less efficient one, the rate of stabiliser depletion will decrease, whereas the amount of heat and nitrogen oxide production as well as the rate of nitrocellulose degradation will increase. In the case of incompatibility testing, heat and gas evolution often (but not always) correlate well with each other but rarely with stabiliser depletion and molecular mass reduction.

As a consequence, a reliable stability assessment of an unknown explosive com- position (or a reliable compatibility assessment of an unknown contact pair) requires first comprehensive knowledge and sound experience in the field, and second a thorough and well-designed testing strategy comprising of several tests analysing different ageing effects.

At the moment, efforts are under way to further investigate the stability and compatibility of explosives as well as to harmonise and improve the international standards for stability and compatibility testing.

\section{Acknowledgements}

The author thanks all co-workers who have contributed to this work, in particular Ruth Sopranetti and her team. The thorough review of the paper by Hanspeter Andres is acknowledged. Special thanks go to Manfred Bohn from ICT, Germany, to Stephan Wilker from WIWEB, Germany, as well as to Beat Berger, Patrick Folly, Fritz Tschan, Hans Stucki and Jürg Mathieu from armasuisse for contributions and interesting discussions. Financial support by armasuisse is gratefully acknowledged (LFP-Project 135015). The author thanks Hansruedi Bircher for supporting this project.

Received: March 30, 2004

[1] G.B. Manelis, G.M. Nazin, Y.I. Rubtsov, V.A. Strunin, 'Thermal Decomposition and Combustion of Explosives and Propellants', Taylor \& Francis Group, London and Berlin, 2003, and references therein.

[2] 'Recommendations on the Transport of Dangerous Goods, Manual of Tests and Criteria', third revised edition, United Nations, New York and Geneva, 1999, p. 117-119 and 124-125.

[3] G. Holl, Opening Presentation at the Forum 'Explosivstoffe', WIWEB, Germany, 1999.

[4] B. Vogelsanger, R. Sopranetti, B. Ossola, K. Ryf, 'Compatibility and Service Life
Predictions of Propulsion/Ammunition Systems', 12th Symp. on Chemical Problems Connected with the Stability of Explosives, Karlsborg, Sweden, 2001.

[5] M.A. Bohn, 'The use of Kinetic Equations to Evaluate the Ageing Behaviour of Energetic Materials - Possible Problems', 11th Symp. on Chemical Problems connected with the Stability of Explosives, Bastad, Sweden 1998; M.A. Bohn, 'Möglichkeiten zur Voraussage der Nutzungsdauer von Treibmitteln mit Stabilisatorabnahme, Molmassenabnahme und anderen Messgrößen', Forum 'Explosivstoffe', WIWEB, Germany, 2000.

[6] L. Druet, M. Asselin, J. Energetic Materials, 1988, 6, 27.

[7] G. Albrecht, Militärtechnik, 1987, 5, 267.

[8] H. Stucki, 'Prüfung der Verträglichkeit von Explosivstoffen mit diversen Materialien', armasuisse Report Nr. TA-6-SIG Sti-22.10/2334, 1980.

[9] S. Wilker, 'Verträglichkeitsuntersuchungen organischer Explosivstoffe mit Kontaktstoffen 1995-2000', WIWEB Germany, Report Nr. 710/24117/00, 2000.

[10] A. Hahma, M. Hihkiö, K. Pihlaja and E. Kantolahti, 'Microcalorimetric Measurements of Compatibilities of Paints with Selected Energetic Materials', Internat. Symp. on Energetic Materials Technology, American Defence Preparedness Association, 1995.

[11] J. Petrz̃ílek, S. Wilker, G. Pantel, L. Stottmeister, 'Compatibility Studies of Flame Retardants in Propellants', to be published.

[12] B. Berger, armasuisse, unpublished results.

[13] P. Guillaume, M. Rat, G. Pantel, S. Wilker, Propellants, Explosives, Pyrotechnics 2001, 26, 51-57. 